\title{
Farmers' Perceptions of and Adaptations to Climate Change in Southeast Asia: The Case Study from Thailand and Vietnam
}

\author{
Hermann Waibel, Thi Hoa Pahlisch, and Marc Völker
}

\begin{abstract}
The perceptions of climate change and adaptation choices made by farmers are important considerations in the design of adaptation strategies by policy makers and agricultural extension services. This paper seeks to determine these perceptions and choices by farmers in already poor environmental regions of Thailand and Vietnam especially vulnerable to climate change. Overall findings were that farmers do perceive climate change, but describe it in quite distinct ways and that location influences how farmers recognize climate change. Our 2007 and 2013 surveys show that farmers are adapting, but it is difficult to determine if specific practices are "climate smart". Further, adaptation measures are informed by perception and, at least in the case of Vietnam, perceptions are shaped by the respondent's characteristics, location variables and recent climate related shocks. Finally, the three climate variables of rainfall, temperature, and wind are the most important factors in explaining specific adaptation measures chosen by farmers. Farmer participation is an essential part of public actions designed to allow adaptation to climate change. Our research can also contribute to understanding farmer constraints and tailoring good overall strategies to the local heterogeneity of vulnerable locations.
\end{abstract}

H. Waibel $(\bowtie) \bullet$ T.H. Pahlisch

Institute of Development and Agricultural Economics, Leibniz Universität Hannover,

Hannover, Germany

e-mail: waibel@ifgb.uni-hannover.de

M. Völker

Institute for Population and Social Research, Mahidol University, Salaya, Thailand

e-mail: marc.voe@mahidol.edu 


\section{Introduction}

As established by the Intergovernmental Panel on Climate Change (IPCC 2014), climate change is affecting Southeast Asia through increasing average temperatures, sea level rise and changes in precipitation, although trends differ strongly across the region. Countries in Southeast Asia are especially vulnerable to the downside effects of global climate change because of (i) their long coastlines, (ii) high concentration of human and economic activities in coastal areas, (iii) large and growing populations, and (iv) the importance of agriculture as a source of employment and income (ADB 2009). Climate change can have especially negative consequences for agricultural productivity and food security (Iglesias et al. 2011). In Thailand, Boonpragob (2005) found that between 1991 and 2002 the country's agriculture experienced crop yield losses worth some 50 billion Thai Baht (approximately 1.3 billion EURO). In Vietnam, which ranks among the top five countries most affected by rising sea levels (Dasgupta et al. 2007), the impact of extreme weather has led to the damage of rice fields by frequent flooding, for example in the Red River Delta, Central Region, and the Mekong Delta. At the same time, rice areas affected by droughts doubled from some 77,000 ha in 1979-1983 to over 175,000 ha in 1994-1998 (Cuong 2008).

To reduce their vulnerability to the negative effects of climate change, farmers must adapt (Gbetibouo 2009). Adaptation measures should be both technically appropriate and economically feasible. In agriculture, adaptations to climate change will require new technologies and investments. Farmers may have to adopt new crop varieties and new livestock breeds, change their cropping systems and invest in new soil and water conservation methods.

In this paper, we explore climate change in Thailand and Vietnam from the perspective of households living in less favored rural areas who are especially vulnerable to the effects of climate change. We focus on three provinces in Northeast Thailand and three provinces in the Central Highlands and North Central Coast of Vietnam. The study makes use of a database of some 4000 households in these two countries collected as an ongoing research project since 2007 entitled "Impact of Shocks on the Vulnerability to Poverty: Consequences for Development of Emerging Southeast Asian Economies" (DFG FOR 756). We mainly use the 2013 survey as it contained a module on climate change. In addition, the survey included questions on household member characteristics, assets, income and consumption, past shock experience, expected risks and individual risk attitudes.

We aim to answer the following questions:

1. What climate-related shocks did farm households experience, what observations did they make about changes in climate over time and what indicators did they use to describe climate change?

2. What determines the farmers' perceptions of climate change and their decision to adjust agricultural production in response to the effects of perceived climate change?

3. What explains the choice of agricultural adaptation measures by farm households? 
The answers to these questions are important for the design of policies and projects aimed to help farmers living in poor environments to adapt to climate change. The participation of farm households in public actions aiming to mitigate or adapt to the impacts of climate change depends on the willingness of these households to participate. Our research can also contribute to the interpretation of the results of climate change models that may have a good overall geographic perspective but may miss the heterogeneity that exists at local levels.

The paper proceeds as follows: Section 2 presents the theoretical background for the determinants of individual climate change perceptions and adaptation behavior. Section 3 describes data collection and Section 4 describes the methodology. Section 5 reports some descriptive results as background information. Section 6 discusses results of our models. Finally, in Section 7, summary and policy conclusions are submitted.

\section{Theoretical Background}

In principle farmers' adaptation to climate change can be modeled using the framework of technology adoption. Generally adoption of technologies depends on a number of factors such as financial incentives, access to extension services and markets but also perceptions and behavior. There is, however, a difference between conventional technology adoption and climate adaptation. While adoption of new technologies mostly aims at increasing profits, adjustments to climate change are often undertaken to reduce risks and to minimize future losses, both of which are directly affected by perceptions of current and future change. It is therefore necessary to incorporate farmers' perception of climate change in an adoption model (Maddison 2007).

Weber (2010) found that people's perception of climate change both in terms of its existence and extent are shaped by learning from personal experience and by making use of statistical information. The formation of perceptions depends on the trust that people attribute to climate scientists and their social amplifiers. Perceptions, however, are only meaningful when they can be linked to actual adaptation measures (Reilly and Schimmelpfennig 1999).

Theoretical insights about the relationship between risk perception and the adoption of risk management actions can be gained from the psychology and economics literature. The psychology literature (e.g. Fuster 2002) refers to the perceptionaction cycle, where people prepare themselves for perceived future outcomes, including the perceived seriousness of potential outcomes. From the economics literature, we can learn that it is necessary to distinguish between gain and loss domain (Kahneman et al. 1990). Tversky and Kahneman (1992) have shown people tend to weigh potential losses higher than potential gains.

Traditionally, adoption decisions have been analyzed in a utility maximization framework with profit as the primary motive (Greene 2003; Norris and Batie 1987). Accordingly, a technology is adopted when the perceived utility or net profit from 
adoption is significantly larger than not adopting it. The adoption decision is subject to a set of exogenous variables such as household characteristics, socioeconomic and physical factors (Feder et al. 1985). More recent models of climate change adaptations have been developed for African countries (Maddison 2007; Deressa et al. 2008; Gbetibouo 2009). These models incorporated climate change perceptions as explanatory variable. We follow this approach to model the factors that influence climate change perceptions and related adaptation measures as well as to explain specific climate change adaptation measures.

\section{Study Regions and Data}

We focus on the 2900 households from the DFG FOR 756 that are engaged in agricultural production because we are interested in the connection between climate change perception and consequences for agriculture. In Thailand, the provinces are Buri Ram, Nakhon Phanom and Ubon Ratchathani located in the Northeastern region of the country. In Vietnam, the provinces are Ha Tinh and Thua Thien Hue located in the North Central Coast region and Dak Lak situated in the Central Highlands. All six provinces are dominantly agricultural areas albeit with a large degree of heterogeneity in development potential. The provinces are bordering neighboring Laos and/or Cambodia. The choice of the provinces was motivated by the assumption that people in rural and geographically remote regions are more vulnerable than people in urban and central regions. Furthermore, these provinces belong to the poorer environments with less developed infrastructure in agriculture and a high potential for climate-related shocks and thus are more likely to be affected by climate change (Waibel et al. 2013).

The survey instruments comprise of a village head and a household questionnaires. The village head questionnaire contains information on the physical and social infrastructure of the village. The household questionnaire has a detailed shock section that included questions about past climate-related shock experience and details about shock severity in terms of income and asset loss (using a 4 point ordinal scale). ${ }^{1}$ A special module on climate change was included where respondents were asked whether or not they had perceived a change in climate in the time that they had lived in their location. Respondents were also asked how they thought that changes in climate is affecting their agriculture (e.g. lower yield, more crop failure) and what measures they had taken to adapt to climate change (e.g. change crop varieties, invest more in irrigation, planting trees, etc.). Part of the household questionnaire was a simple risk item that measures respondents' general attitude towards risk on an 11 point Likert scale following Dohmen et al. (2011) and Hardeweg et al. (2013).

\footnotetext{
${ }^{1} 0=$ no impact, $1=$ low impact, $2=$ medium impact, $3=$ high impact.
} 


\section{Empirical Strategy}

We address question 1 through a descriptive analysis of the household survey data, and question 2 by employing an econometric model (model 1) that allows us to establish a link between climate change perceptions and adaptation decisions. Question 3 is addressed through a second model (model 2).

The first model is a two-stage procedure. In the first stage, perception of climate change is specified as the outcome variable. In the second stage, adaptation is the outcome variable for respondents who reported awareness of climate change. Accordingly, households in the second stage are non-randomly selected from the entire sample.

To deal with potential selection bias, a Heckman's selection probit model was specified. We consider a random sample of $i$ observations. Equations for individual $i$ are:

$$
\begin{aligned}
& Y_{1 j}=X_{1 j} \beta_{1}+U_{1 i} \\
& Y_{2 i}=X_{2 i} \beta_{2}+U_{2 i}
\end{aligned}
$$

where $X_{j i}$ is a $1 \times K_{j}$ vector of regressors, $\beta_{j}$ is a $K_{j} \times 1$ vector of parameters, and

$$
E\left(U_{i j}\right)=0, E\left(U_{j i} U_{j^{\prime} j^{\prime \prime}}\right)=\sigma_{j j^{\prime}}, i=i^{\prime \prime} \text { and } E\left(U_{j i} U_{j^{\prime} j^{\prime \prime}}\right)=0, i \neq i^{\prime \prime}
$$

Suppose that $Y_{1 i}$ is observed only if $Y_{2 i} \geq 0$. In the case of independence between $U_{1 i}$ and $U_{2 i}$ or $E\left(U_{j i} U_{j^{\prime} j^{\prime \prime}}\right)=0$ so that the data available on $Y_{1 i}$ are missing randomly, the regression function for the selected subsample is the same as the population regression function. In the general case where $E\left(U_{j i} U_{j^{\prime} j^{\prime \prime}}\right)=\sigma_{j j^{\prime}}$, least squares estimators yield biased results. Thus, the Heckman selection model as a solution in providing consistent, efficient estimates in the following way:

$$
\begin{gathered}
E\left(Y_{1 i} \mid X_{1 i}, Y_{2 i} \geq 0\right)=X_{1 i} \beta_{1}+\frac{\sigma_{12}}{\left(\sigma_{22}\right)^{1 / 2}} \lambda_{i} \\
E\left(Y_{2 i} \mid X_{2 i}, Y_{2 i} \geq 0\right)=X_{2 i} \beta_{2}+\frac{\sigma_{22}}{\left(\sigma_{22}\right)^{1 / 2}} \lambda_{i}
\end{gathered}
$$

where $\lambda_{i}=\frac{\phi\left(Z_{i}\right)}{1-\Phi\left(Z_{i}\right)}$ and $Z_{i}=-\frac{X_{2 i} \beta_{2}}{\left(\sigma_{22}\right)^{1 / 2}}$ with $\phi$ and $\Phi$ are, respectively, the density and distribution function for a standard normal variable (Heckman 1979).

In our analysis, $Y_{1 i}$ is a binary variable specifying whether or not household $i$ adapts their agricultural activities to climate change. $Y_{2 i}$ is a binary variable taking on the value unity if respondent of household $i$ perceived climate change and zero otherwise. $X_{1 i}$ is a vector of explanatory variables for the outcome Equation (1a). 
$X_{2 i}$ is a vector of explanatory variables for the selection Equation (1b). It is not absolutely necessary to have the exclusion restriction in the Heckman selection model (Wooldridge 2009) and in some cases the vectors of explanatory variables for selection equation and outcome equation are even identical (Puhani 2000). Thus, the justification for inclusion of variables for $X_{1 i}$ and $X_{2 i}$ is merely based on the expected effect of these variables on the dependent variables $Y_{1 i}$ and $Y_{2 i}$ respectively.

$X_{1 i}$ includes household head characteristics (age, education, gender, membership of socio-political organization), household characteristic (agricultural member ratio, farm size, income, risk attitude and ethnicity in the model for Vietnam), and distance to district town and province dummies.

Based on the study of Gbetibouo (2009), there is no agreement in the adoption literature on the effect of age of household head. Age can be found to have negative influence on the adoption decision of new technologies because older farmers are more risk-averse than younger farmers and thus have a lesser likelihood of adopting. It is also possible however that older farmers have more farming experiences enabling them to better judge the merits of new technology.

Education is believed to increase the probability of accessing information (Norris and Batie 1987). Evidence from previous studies shows a positive influence of household head's education on the decision to adapt to climate change (Deressa et al. 2008; Maddison 2007). Therefore, we expect that education level of household head is positively related with adaptations to climate change.

We expect that male household heads are more likely to gain information on new technologies and are more likely to be risk takers (Asfaw and Admassie 2004). Therefore, the likelihood of male-headed households to adapt to climate change is believed to be higher than that of female-headed households.

Membership in a social-political organization is hypothesized to have a positive effect on the adaptation decision. It is considered as one kind of social capital of the farmers and as a member of such organization, household heads may have more opportunities to learn new agricultural practices than other members.

Household characteristics used in explaining the adaptation decision include agricultural member ratio, farm size, income and risk attitude. Agricultural member ratio is defined as the ratio between number of household members aged from 15 to 64 engaged in its own agricultural production and the total number of household members in that age range. This ratio is expected to positively influence the decision to adapt to climate change. This enables household to accomplish various agricultural tasks even at peak times. This hypothesis is based on the study of Croppenstedt et al. (2003) revealing that larger amount of labor increases the household's probability of adopting agricultural technology and using it more intensively.

The effect of farm size on the adaptation to climate change is ambiguous. Gbetibouo (2009) found a positive relationship between farm size and the adaptation to climate change. The author also argued that adoption of an innovation tends to take place earlier on larger farms than on smaller farms. On the contrary, farm size showed a negative effect on the adaptation decision in the study Deressa et al. (2008) which is perhaps due to plot level heterogeneity.

We hypothesize that households with higher income will be more likely to undertake adaptation measures. Similarly, if household has larger capital endowment, it 
has a better possibility to invest (e.g. Franzel 1999). We further hypothesize that in households where the respondent (household head) expresses a lower degree of risk aversion she is more likely to undertake adaption measures.

In the model for Vietnam, we included ethnicity as a binary variable taking on the value 1 if household is the majority Kinh and 0 if household belongs to any of the many ethnic minorities. We expect that ethnic minorities are less likely to invest in climate change related adaptation measures due to their living in the remote areas and villages less endowed with infrastructure (Hung et al. 2010).

To capture the effect of remoteness for all households we added the variable "Distance to district town" from the village head questionnaire. Here we expect a negative relationship with climate change adaptation. Finally, we added province dummy variables to capture other differences among the study regions.

In the selection Equation (1b), we use the respondent characteristics including age, education, gender and membership of socio-political organization as the independent variables. This is because the adaptation decision is made by the household head but the perception of climate change is given by the respondent of that household who in most cases is the household head. Age, a proxy of farming experience, is supposed to have a positive effect on the farmers' awareness. We expect that more experienced farmers are more likely to observe changes in climate over time. Likewise, better educated farmers are believed to have more access to information on climate change (Deressa et al. 2008). Household size is assumed to have a positive effect as the chance to obtain information increases with the number of household members and the same mechanism we assume for income (Deressa et al. 2008).

One important household characteristic included as an explanatory variable in the selection equation is the climate-related shock experience. This variable is computed by summing up the severity scores multiplied by the frequencies of all climatic events, namely drought, floods, storm and soil erosion experienced by a household in the reference period. We expect that more experience with negative climate-related shocks in the past increases the probability that a respondent is aware of climate change.

The inclusion of the ethnicity variable in the model for Vietnam is based on the same arguments as in Equation 1a. We expect that the Kinh majority is more likely to be aware of climate change. Likewise, we have added province dummy variables. In order to control for country heterogeneity we estimate models for Thailand and Vietnam separately.

In order to further explore the type of adaptation measures undertaken by farmers, we formulated a multinomial logit model (MNL) to assess the drives for four categories of adaptation measures, while not undertaking any adaptation was treated as the base category as follows:

$$
\operatorname{Pr}\left(Y_{i}=j\right)=\frac{\exp \left(x \beta_{j}\right)}{\sum_{k=1}^{J} \exp \left(x \beta_{k}\right)}
$$


where the dependent variable $Y$ denotes adaptation categories taking on value $\mathrm{j}=$ $\{0,1,2, \ldots \mathrm{J}\}$ and $x$ is a vector of regressors (Greene 2003).

In our study, the adaptation categories include the following:

- $0=$ No adaptation

- 1 = Crop diversification

- 2 = Chemical input management

- 3 = Water management

- 4 = Planting trees

The explanatory variables $x$ include different household head characteristics (i.e. age, education, gender, membership of socio-political organization), household characteristic (agricultural member ratio, farm size, income, risk attitude and ethnicity (only in model for Vietnam)), distance to district town and province dummies. The justification of these variables and their expected direction of influence are assumed to be identical with those in Equation 1a.

In addition, however, we include the respondent's perceptions of changes in climate-related parameters like rainfall, temperature and wind as these perceptions may influence the choice of adaptation measures in different ways. The multinomial logit model makes the assumption of independence of irrelevant alternatives (IIA) (Long and Freese 2006). We use the Hausman test to verify this assumption.

\section{Descriptive Results}

In the shock section of the survey, households were asked for the four most frequent types of climate-related shocks (i.e. droughts, floods, storms and soil erosion) experienced during the past 3 years (2010-2013). Table 1a reports these results for Thailand and Table $1 \mathrm{~b}$ for Vietnam. As shown in Table 1a, drought was the major climaterelated shock event reported with a considerable variation across the three provinces in Thailand. The province of Buri Ram was most affected. Flood was reported by over $10 \%$ of households in two provinces while storms and soil erosion was reported by only few households. Average frequency of climate events was little over one event

Table 1a Climate-related shocks experienced by farmers by province in Thailand

\begin{tabular}{|c|c|c|c|c|c|c|c|c|c|}
\hline \multirow{2}{*}{$\begin{array}{l}\text { Type of } \\
\text { climate- } \\
\text { related } \\
\text { shocks }\end{array}$} & \multicolumn{3}{|c|}{$\%$ of households reported } & \multicolumn{3}{|c|}{ Average frequency } & \multicolumn{3}{|c|}{ Average severity } \\
\hline & $\begin{array}{l}\text { Buri } \\
\text { Ram }\end{array}$ & $\begin{array}{l}\text { Ubon } \\
\text { Ratcha- } \\
\text { thani }\end{array}$ & $\begin{array}{l}\text { Nakhon } \\
\text { Phanom }\end{array}$ & $\begin{array}{l}\text { Buri } \\
\text { Ram }\end{array}$ & $\begin{array}{l}\text { Ubon } \\
\text { Ratcha- } \\
\text { thani }\end{array}$ & $\begin{array}{l}\text { Nakhon } \\
\text { Phanom }\end{array}$ & $\begin{array}{l}\text { Buri } \\
\text { Ram }\end{array}$ & $\begin{array}{l}\text { Ubon } \\
\text { Ratcha- } \\
\text { thani }\end{array}$ & $\begin{array}{l}\text { Nakhon } \\
\text { Phanom }\end{array}$ \\
\hline Drought & 58.57 & 21.27 & 16.84 & 1.00 & 1.00 & 1.08 & 2.49 & 2.43 & 2.39 \\
\hline Flood & 6.96 & 11.21 & 13.68 & 1.02 & 1.00 & 1.05 & 2.37 & 2.51 & 2.63 \\
\hline Storm & 4.41 & 1.21 & 3.16 & 1.00 & 1.00 & 1.00 & 2.54 & 2.00 & 1.78 \\
\hline $\begin{array}{l}\text { Soil } \\
\text { erosion }\end{array}$ & 0.34 & 0.91 & 0.00 & 1.00 & 1.00 & - & 2.00 & 2.50 & - \\
\hline
\end{tabular}

Source: DFG Household survey 2013 
Table 1b Climate-related shocks experienced by farmers by province in Vietnam

\begin{tabular}{|c|c|c|c|c|c|c|c|c|c|}
\hline \multirow{2}{*}{$\begin{array}{l}\text { Type of } \\
\text { climate- } \\
\text { related } \\
\text { shocks }\end{array}$} & \multicolumn{3}{|c|}{$\%$ of households reported } & \multicolumn{3}{|c|}{ Average frequency } & \multicolumn{3}{|c|}{ Average severity } \\
\hline & $\begin{array}{l}\text { Ha } \\
\text { Tinh }\end{array}$ & $\begin{array}{l}\text { Thua } \\
\text { Thien } \\
\text { Hue }\end{array}$ & $\begin{array}{l}\text { Dak } \\
\text { Lak }\end{array}$ & $\begin{array}{l}\mathrm{Ha} \\
\text { Tinh }\end{array}$ & $\begin{array}{l}\text { Thua } \\
\text { Thien } \\
\text { Hue }\end{array}$ & $\begin{array}{l}\text { Dak } \\
\text { Lak }\end{array}$ & $\begin{array}{l}\mathrm{Ha} \\
\text { Tinh }\end{array}$ & $\begin{array}{l}\text { Thua } \\
\text { Thien } \\
\text { Hue }\end{array}$ & $\begin{array}{l}\text { Dak } \\
\text { Lak }\end{array}$ \\
\hline Drought & 13.23 & 14.37 & 47.48 & 1.00 & 1.00 & 1.04 & 2.37 & 2.58 & 2.65 \\
\hline Flood & 36.38 & 13.97 & 3.47 & 1.03 & 1.03 & 1.00 & 2.55 & 2.60 & 2.59 \\
\hline Storm & 8.56 & 8.58 & 0.79 & 1.00 & 1.00 & 1.00 & 2.43 & 2.51 & 1.80 \\
\hline Soil erosion & 0.58 & 3.19 & 0.47 & 1.67 & 1.00 & 1.00 & 3.00 & 2.38 & 2.67 \\
\hline
\end{tabular}

Source: DFG Household survey 2013

and quite consistent across the provinces. The same can be said for perceived severity which is mostly around 2.5 on average on scale from 0 to 3 . This severity score implies that climatic extreme events affected farm households quite critically according to their subjective assessment. Overall, among the three provinces in Thailand, Buri Ram province located in the eastern part of the country and on the border with Cambodia had the highest degree of climate-related shocks reported.

From Table $1 \mathrm{~b}$ it can be derived that results vary considerable across the three provinces in Vietnam. In the land locked province of Dak Lak where coffee is a major crop drought was reported by almost half of the households and storm was reported by just few households. On the other hand in Ha Tinh, the province located in the central coastal region with exposure to the sea, more households reported floods. Drought, flood and storm were reported with quite similar rates of households in Thua Thien Hue. This is also the province where soil erosion was most experienced. Frequency of events was similar to Thailand with the exception of soil erosion in Ha Tinh, which can be explained by the mountainous terrain where some of the sample households are located. This observation is also reflected in the perceived severity which is higher than for the other categories. Overall, severity is somewhat higher in the Vietnamese provinces compared to the provinces in Thailand. This seems reasonable as Vietnam is generally more severely affected by the climate change.

In the climate change module, we asked respondents whether or not they perceived changes in climate in general and changes in rainfall, temperature and wind in particular during the time they resided in the area. In Table 2, the different variants of climate change for the three climate categories are reported.

Overall, the vast majority of respondents in all six provinces in the two countries have recognized changes in climate and changes in rainfall and temperature were more frequently reported than changes in wind. Results do not differ much between the two countries although variation between provinces remains high.

Changes in rainfall patterns were described differently between provinces and countries. For example, in two provinces of Thailand respondents observed the length of the dry season to have increased while in Vietnam lower total rainfall was more noted. However, in Vietnam households perceived rainfall variability to increase. Differences among provinces in both countries may show the difference of their geographic conditions. 
Table 2 Climate change perceptions of farmers in Thailand and Vietnam by province, percentage of households reported

\begin{tabular}{|c|c|c|c|c|c|c|}
\hline \multirow[b]{2}{*}{ Observations } & \multicolumn{3}{|c|}{ Thailand } & \multicolumn{3}{|c|}{ Vietnam } \\
\hline & $\begin{array}{l}\text { Buri } \\
\text { Ram }\end{array}$ & $\begin{array}{l}\text { Ubon } \\
\text { Ratchathani }\end{array}$ & $\begin{array}{l}\text { Nakhon } \\
\text { Phanom }\end{array}$ & $\begin{array}{l}\mathrm{Ha} \\
\text { Tinh }\end{array}$ & $\begin{array}{l}\text { Thua Thien } \\
\text { Hue }\end{array}$ & Dak Lak \\
\hline Climate in general & 94.57 & 90.61 & 74.74 & 81.52 & 82.04 & 90.69 \\
\hline Rainfall & 94.51 & 88.79 & 68.98 & 78.30 & 80.40 & 89.19 \\
\hline $\begin{array}{l}\text { Less rain in the } \\
\text { whole year }\end{array}$ & 40.08 & 24.26 & 11.63 & 25.95 & 42.44 & 46.09 \\
\hline $\begin{array}{l}\text { Less rain early in } \\
\text { the season }\end{array}$ & 23.26 & 16.70 & 14.68 & 2.12 & 15.12 & 13.80 \\
\hline $\begin{array}{l}\text { Dry season becomes } \\
\text { longer }\end{array}$ & 49.15 & 38.33 & 16.90 & 19.42 & 24.69 & 28.02 \\
\hline $\begin{array}{l}\text { Rain becomes more } \\
\text { erratic }\end{array}$ & 16.43 & 33.18 & 9.97 & 30.35 & 19.91 & 37.13 \\
\hline Fewer rainy days & 15.11 & 12.70 & 4.99 & 12.75 & 21.45 & 29.87 \\
\hline Temperature & 94.41 & 90.27 & 72.85 & 76.93 & 77.16 & 86.77 \\
\hline $\begin{array}{l}\text { Getting hotter in } \\
\text { summer }\end{array}$ & 86.86 & 87.64 & 55.68 & 55.08 & 61.57 & 63.02 \\
\hline $\begin{array}{l}\text { Cool season is } \\
\text { shorter }\end{array}$ & 35.35 & 41.53 & 15.24 & 20.49 & 28.24 & 9.96 \\
\hline $\begin{array}{l}\text { More extreme } \\
\text { temperature }\end{array}$ & 18.00 & 37.64 & 20.20 & 57.21 & 45.22 & 54.91 \\
\hline More heat days & 59.53 & 62.36 & 17.45 & 23.07 & 52.47 & 56.19 \\
\hline Wind & 80.81 & 67.39 & 54.85 & 34.14 & 27.93 & 37.84 \\
\hline Wind speed higher & 71.62 & 60.18 & 46.54 & 21.4 & 19.60 & 32.43 \\
\hline $\begin{array}{l}\text { More frequent } \\
\text { storms }\end{array}$ & 31.14 & 34.67 & 16.62 & 8.65 & 8.80 & 1.71 \\
\hline $\begin{array}{l}\text { Wind direction } \\
\text { changes }\end{array}$ & 24.54 & 31.01 & 12.19 & 13.51 & 13.73 & 11.52 \\
\hline
\end{tabular}

Source: DFG Household survey 2013

Temperature results generally follow those of rainfall. However, there is more agreement on the description of the type of temperature changes with most respondents observing higher summer temperatures. Both in Thailand and Vietnam over half the respondents in two provinces said that extreme temperatures have increased.

Changes in wind were less frequently mentioned especially in Vietnam while in the province of Buri Ram $80 \%$ of the respondents specified a higher wind speed as major change and $30 \%$ reported more frequent storms which was confirmed by respondents from the province of Ubon Ratchathani.

Comparing farmer observations with existing literatures supports the notion that their subjective perceptions match scientific data. This confirms findings from South Africa that farmers' perceptions of climate change are in line with the climatic data records (Gbetibouo 2009). Meteorological data from Thailand confirm that rainfall in Thailand decreased in the past three to five decades compared to the first half of 
Table 3 Effects of climate change on crop production and farmers' adaptation measures by province, percentage of households reported

\begin{tabular}{|c|c|c|c|c|c|c|}
\hline & \multicolumn{3}{|c|}{ Thailand } & \multicolumn{3}{|c|}{ Vietnam } \\
\hline & $\begin{array}{l}\text { Buri } \\
\text { Ram }\end{array}$ & \begin{tabular}{|l} 
Ubon \\
Rathchathani
\end{tabular} & $\begin{array}{l}\text { Nakhon } \\
\text { Phanom }\end{array}$ & $\begin{array}{l}\text { Ha } \\
\text { Tinh }\end{array}$ & $\begin{array}{l}\text { Thua } \\
\text { Thien Hue }\end{array}$ & Dak Lak \\
\hline $\begin{array}{l}\text { Effects on crop } \\
\text { production }\end{array}$ & 81.66 & 68.48 & 44.91 & 71.21 & 64.47 & 84.07 \\
\hline Lower yields & 61.89 & 47.48 & 32.41 & 45.83 & 41.82 & 63.87 \\
\hline More crop failures & 25.23 & 27.69 & 9.97 & 28.83 & 17.75 & 32.72 \\
\hline More pests & 15.77 & 12.47 & 1.94 & 29.29 & 26.70 & 21.62 \\
\hline More drought stress & 35.35 & 23.46 & 7.20 & 10.77 & 15.74 & 34.99 \\
\hline $\begin{array}{l}\text { Adaptation } \\
\text { measures }\end{array}$ & 29.54 & 32.42 & 11.23 & 45.53 & 31.14 & 44.95 \\
\hline Crop diversification & 19.69 & 21.82 & 6.67 & 13.62 & 11.38 & 20.82 \\
\hline $\begin{array}{l}\text { Chemical input } \\
\text { management }\end{array}$ & 12.05 & 11.52 & 4.56 & 22.96 & 21.76 & 11.04 \\
\hline Water management & 3.40 & 9.42 & 0.70 & 7.39 & 6.39 & 22.40 \\
\hline Planting trees & 1.87 & 2.88 & 0.35 & 0.39 & 1.60 & 0.47 \\
\hline Others & 0.00 & 0.30 & 0.00 & 11.09 & 1.80 & 2.05 \\
\hline
\end{tabular}

Source: DFG Household Survey 2013

the last century. Also climate models predicted that precipitation will shift from the north to the south (Boonyawat and Chiwanno 2007). Based on climate data generated by a global circulation model temperature in Thailand projected to increase $2^{\circ} \mathrm{C}-4{ }^{\circ} \mathrm{C}$ by the end of the century (ADB 2009). Jesdapipat (2008) stated that storms in Thailand have become more intense which is consistent with the subjective perceptions of respondents in our sample.

In Vietnam it has been predicted that most regions will experience an increase in temperature of $2^{\circ} \mathrm{C}-4{ }^{\circ} \mathrm{C}$ by the end of the century (Cuong 2008). The same author also found that in most areas of Vietnam, overall rainfall intensity has increased considerably while monthly rainfall has decreased between the months of July and August, but has increased between September and November. It is also expected that the Southern part of Vietnam will become drier.

In Table 3, we illustrate the perceived impact of climate change by farmers on the performance of agriculture, in particular in crop production and their adaptation measures. It is striking that in all six provinces of the two countries a considerable share of households reports a decline in yields. The highest shares with over $60 \%$ of households reporting are in Buri Ram and Dak Lak, both provinces with a strong agricultural potential. In these two provinces the occurrence of drought stress was most frequent which is quite consistent with their observations on the change in climate generally and in rainfall reported in Table 2.

In spite of the high share of households who report an impact on crop production only between one fourth and two fifth undertake adaptation measures. This kind of discrepancy has also been observed in a study of farmers in Ethiopia 
(Deressa et al. 2008). Adaptation measures include for example growing more (drought resistant) varieties, widening the crop portfolio, spraying more pesticides and applying more fertilizer. Although responses considerably vary by country and by province reflecting differences in agricultural systems, changes in crops and crops varieties and in the amount of chemical input used are the two dominant adaptation measures. In the province of Dak Lak, investment in irrigation was reported by over one fifth of households which is distinctively higher than in all other provinces. Here results are consistent with the perception of more droughts which however is not the case for the province of Buri Ram where 35.35\% farmers reported drought stress but only $3.40 \%$ take a particular water management method.

In summary, what we can derive from the survey on subjective climate change perceptions is that there is a strong geographic effect of the perceived impacts of climate change. The fact that there is a fairly good congruence between the perceived effects of climate change and adaptations suggesting that farmers are well aware of climate change although the ratio of adaptations to perceptions is in the order of 1:3 only.

In Table 4, we have made use of the 2007 survey and compared farm management parameters related the use chemical inputs, irrigation practices and tools and tree plantation which can serve as proxy parameters for actual adjustment to climate change with the 2013 survey data. It shows that changes can be observed with more cases significant in Vietnam. While no causality to climate change perception can be established here and other factors can also play a role, results are consistent with respondents' climate change perceptions. For example, planting of trees has increased significantly in both countries.

Summarizing the results of the descriptive analysis suggests that farmers in poor and vulnerable environments in Thailand and Vietnam did experience climaterelated shocks which on average are perceived as moderately severe. However, variation across locations exists. Furthermore, farmers are well aware of climate change and can describe the process by a range of indicators like "cool season getting shorter" or "rain become more erratic". These criteria differ from those used by scientists in climate models but they seem to correspond well with such findings.

Table 4 Farm management practices in 2007 and 2013 across all provinces in Thailand and Vietnam

\begin{tabular}{l|l|l|l|l|l|l}
\hline \multirow{2}{*}{ Parameter } & \multicolumn{2}{l}{ Thailand } & \multicolumn{2}{l}{ Vietnam } \\
\cline { 2 - 7 } & 2007 & 2013 & p-value & 2007 & 2013 & p-value \\
\hline Chemical input (PPP\$) & 35.41 & 55.45 & 0.02 & 118.36 & 93.83 & 0.02 \\
\hline Irrigation tools (unit) & 1.89 & 1.73 & 0.63 & 0.90 & 2.29 & 0.00 \\
\hline Newly-bought irrigation tools (unit) & 0 & 0.030 & 0.00 & 0 & 0.004 & 0.08 \\
\hline Share of irrigated plots (\%) & 13.98 & 7.71 & 0.00 & 50.64 & 71.31 & 0.00 \\
\hline Share of tree areas (\%) & 4.91 & 8.09 & 0.00 & 23.84 & 34.19 & 0.00 \\
\hline Share of trees out of crop types (\%) & 5.95 & 10.37 & 0.00 & 20.58 & 30.21 & 0.00 \\
\hline
\end{tabular}

Source: DFG Household Survey 2007-2013 
Also, farmers recognize that climate change has caused negative impacts on their agricultural production. Nevertheless, adaptation actions in response to the perceived downside effects are still few. This underlines the hypotheses established in Section 2 of the paper that perceptions are an important driver for adaptation decisions that aim at reducing risks and losses. In the next section the perception-adoption link will be explored further by means of econometric analysis.

\section{Results of Econometric Analysis}

With our first model we test the hypothesis that farmers' perception of climate change can be linked to the likelihood of farmer's respective adaption measures. Our two-step Heckman probit model shows a significant lambda for both Thailand and Vietnam dataset indicating the existence of sampling bias (Tables 5a and 5b). The perception model for Vietnam mostly shows the expected signs of the explanatory variables. Education and gender show positive and significant signs (Table 5a). In other words, better educated and male respondents are more likely to recognize climate change. Climate-related shock experience significantly increases the likelihood of respondents recognizing climate change suggesting that short term experience can shape perceptions for long term trends. Differences in province partly reflect the findings of the descriptive statistics. Relative to the base province of $\mathrm{Ha}$ Tinh, respondents in Dak Lak are significantly more likely to perceive climate change. This result is consistent with those presented in Tables $1 \mathrm{~b}$ and 2 with increasing temperatures and an increase in droughts.

The outcome equation with the implementation of adaptation measures as the dependent variable also shows better statistical quality for Vietnam. Age of household head is negatively related to the likelihood of adaptation measures. It is plausible that older farmers are less likely to change their farming system in response to perceived climate change. Gender was significant suggesting that male household heads are more likely to implement adaptation measures which is consistent with the findings of Asfaw and Admassie (2004). As expected, membership in a sociopolitical organization has a positive influence on adaption measures. Likewise, the share of household members engaged in agriculture and ethnicity of household are positively correlated with likelihood of adaptation.

As shown in Table 5b, the perception model for Thailand overall performed poorly in terms of statistical tests. However, the climate-related shock variable was significant and the significant coefficients of the province dummy variables for Buri Ram (positive) and Nakhon Phanom (negative) were consistent with observations presented in Tables 1a and 2.

Similar to the selection equation, the adaptation model for Thailand showed poor explanatory power and the only significant variable (aside from a province dummy) was the respondent's individual attitude towards risk. The coefficient of risk attitude 
Table 5a Perceptions of and adaptations to climate change by farm households in Vietnam, twostage Heckman selection model

\begin{tabular}{|c|c|c|}
\hline \multirow[b]{2}{*}{ Explanatory variables } & $\begin{array}{l}\text { Adaptation } \\
\text { equation }\end{array}$ & Selection equation \\
\hline & Coefficients & Coefficients \\
\hline \multicolumn{3}{|l|}{ Household head characteristics } \\
\hline \multirow[t]{2}{*}{ Age (Years) } & $-0.004 * * *$ & \\
\hline & $(-2.71)$ & \\
\hline \multirow[t]{2}{*}{ Education (Years of schooling) } & -0.001 & \\
\hline & $(-0.26)$ & \\
\hline \multirow[t]{2}{*}{ Gender $(1=$ Male, $0=$ Female $)$} & 0.058 & \\
\hline & $(1.47)$ & \\
\hline $\begin{array}{l}\text { Member of socio-political organization } \\
(1=\text { Yes, } 0=\text { No })\end{array}$ & $\begin{array}{l}\mathbf{0 . 0 9 0} * * \\
(2.56)\end{array}$ & \\
\hline \multicolumn{3}{|l|}{ Respondent characteristics $^{\mathrm{a}}$} \\
\hline \multirow[t]{2}{*}{ Age (Years) } & & 0.005 \\
\hline & & $(1.45)$ \\
\hline \multirow[t]{2}{*}{ Education (Years of schooling) } & & $0.027 * *$ \\
\hline & & $(2.31)$ \\
\hline \multirow[t]{2}{*}{ Gender $(1=$ Male, $0=$ Female $)$} & & $0.211 * *$ \\
\hline & & $(2.56)$ \\
\hline Member of socio-political organization $(1=$ Yes, $0=\mathrm{No})$ & & $\begin{array}{l}0.035 \\
(0.34)\end{array}$ \\
\hline \multicolumn{3}{|l|}{ Household characteristics } \\
\hline \multirow[t]{2}{*}{ Agricultural member ratio } & $0.227 * * *$ & \\
\hline & $(4.32)$ & \\
\hline \multirow[t]{2}{*}{ Log of farm size (ha) } & $0.029 * *$ & \\
\hline & $(\mathbf{2 . 1 0})$ & \\
\hline \multirow[t]{2}{*}{ Household size } & & 0.022 \\
\hline & & $(0.83)$ \\
\hline \multirow[t]{2}{*}{ Log of income (PPP\$) } & 0.029* & 0.036 \\
\hline & $(\mathbf{1 . 7 2})$ & $(0.84)$ \\
\hline \multirow[t]{2}{*}{ Ethnicity $(1=$ Kinh, $0=$ Minorities $)$} & $0.095 * *$ & -0.113 \\
\hline & $(2.25)$ & $(-0.97)$ \\
\hline Climate-related shock experience (Ordinal score) & & $\begin{array}{l}\text { 0.061** } \\
(2.44)\end{array}$ \\
\hline Risk attitude (Likert scale) & $\begin{array}{l}-0.002 \\
(-0.29) \\
\end{array}$ & \\
\hline \multicolumn{3}{|l|}{ Village characteristics } \\
\hline $\log$ of distance to district town $(\mathrm{Km})$ & $\begin{array}{l}-0.016 \\
(-0.80)\end{array}$ & $\begin{array}{l}\text { 0.089* } \\
(1.81)\end{array}$ \\
\hline \multicolumn{3}{|l|}{ Province dummies } \\
\hline \multirow[t]{2}{*}{ Thua Thien Hue } & $-0.127 * * *$ & 0.087 \\
\hline & $(-2.96)$ & $(0.80)$ \\
\hline Dak Lak & $-0.107 * *$ & $0.405 * * *$ \\
\hline
\end{tabular}


Table 5a (continued)

\begin{tabular}{l|l|l}
\hline \multirow{2}{*}{ Explanatory variables } & $\begin{array}{l}\text { Adaptation } \\
\text { equation }\end{array}$ & Selection equation \\
\cline { 2 - 3 } & Coefficients & Coefficients \\
\hline Intercept & $\mathbf{( - 2 . 0 3 )}$ & $\mathbf{( 3 . 4 5 )}$ \\
\hline & $\mathbf{0 . 4 0 8 *}$ & -0.219 \\
\hline Mills & $\mathbf{( 1 . 8 0 )}$ & $(-0.52)$ \\
\hline Lambda & & \\
\hline rho & $\mathbf{- 0 . 4 8 7 * *}$ & \\
\hline Total observations & $\mathbf{( - 1 . 9 7 )}$ & \\
\hline Wald chi2 & -0.87 & \\
\hline Prob > chi2 & 1529 & \\
\hline
\end{tabular}

Source: Authors' own calculation

Note: ${ }^{*} p<0.10, * * p<0.05, * * * p<0.01$, z statistics in parentheses

${ }^{a}$ We tried to use the household head characteristics instead of respondent characteristics in the perception equation but the results are as not good as results in Tables $5 \mathrm{a}$ and $5 \mathrm{~b}$

shows that the higher the degree of risk-seeking, the higher the likelihood that a household adapts to climate change. While farmers in Buri Ram perceive a higher degree of climate change compared to the reference province of Ubon Ratchathani, fewer farmers undertake adaptation measures. Against this background the negative coefficient for the province dummy is surprising. However, this suggests that other factors such as poorer quality extension services or less attention given by other public institutions to the climate change phenomenon may cause this result.

To investigate the determinants for choosing different adaptation measures, we use a multinomial logit model for four groups of adaptations and "no adaptation" is the base category. The Hausman test for the validity of the independence of the irrelevant alternatives (IIA) was insignificant for both Thailand and Vietnam. This suggests that the multinomial logit model is an appropriate specification for modelling the choice of adaptation measures to climate change of farmers. The estimated coefficients along with the standard errors are presented in Table 6a for Vietnam and in Table $6 \mathrm{~b}$ for Thailand.

In the model for Vietnam, the signs of the explanatory variables are largely consistent with the results of the outcome equation in the Heckman model (Table 5a). For all adaptation measures except for "planting trees" household head' age has a significant and negative signs which is consistent with expectations as older household heads are likely to stick to their traditional practices in spite of recognizing changes in climate conditions. On the other hand, changing water management practices is positively correlated with membership in a socio-political organization. This is plausible as water management in rural Vietnam is a collective action and usually requires good relationships with village authorities namely the people's 
Table 5b Perceptions of and adaptations to climate change by farm households in Thailand, twostage Heckman selection model

\begin{tabular}{|c|c|c|}
\hline \multirow[b]{2}{*}{ Explanatory variables } & $\begin{array}{l}\text { Adaptation } \\
\text { equation }\end{array}$ & Selection equation \\
\hline & Coefficients & Coefficients \\
\hline \multicolumn{3}{|l|}{ Household head characteristics } \\
\hline \multirow[t]{2}{*}{ Age (Years) } & 0.001 & \\
\hline & $(0.93)$ & \\
\hline \multirow[t]{2}{*}{ Education (Years of schooling) } & 0.006 & \\
\hline & $(1.01)$ & \\
\hline \multirow[t]{2}{*}{ Gender $(1=$ Male, $0=$ Female $)$} & 0.034 & \\
\hline & $(0.96)$ & \\
\hline Member of socio-political organization $(1=$ Yes, $0=\mathrm{No})$ & $\begin{array}{l}-0.032 \\
(-0.44)\end{array}$ & \\
\hline \multicolumn{3}{|l|}{ Respondent characteristics } \\
\hline \multirow[t]{2}{*}{ Age (Years) } & & -0.004 \\
\hline & & $(-0.99)$ \\
\hline \multirow[t]{2}{*}{ Education (Years of schooling) } & & 0.004 \\
\hline & & $(0.28)$ \\
\hline \multirow[t]{2}{*}{ Gender $(1=$ Male, $0=$ Female $)$} & & 0.020 \\
\hline & & $(0.20)$ \\
\hline Member of socio-political organization $(1=$ Yes, $0=$ No $)$ & & $\begin{array}{l}-0.039 \\
(-0.17)\end{array}$ \\
\hline \multicolumn{3}{|l|}{ Household characteristics } \\
\hline \multirow[t]{2}{*}{ Agricultural member ratio } & 0.030 & \\
\hline & $(0.53)$ & \\
\hline \multirow[t]{2}{*}{ Log of farm size (ha) } & -0.024 & \\
\hline & $(-1.32)$ & \\
\hline \multirow[t]{2}{*}{ Household size } & & 0.042 \\
\hline & & $(1.39)$ \\
\hline \multirow[t]{2}{*}{ Log of income (PPP\$) } & 0.004 & 0.036 \\
\hline & $(0.23)$ & $(0.77)$ \\
\hline Climate-related shock experience (Ordinal score) & & $\begin{array}{l}0.090 * * * \\
(2.69)\end{array}$ \\
\hline Risk attitude (Likert scale) & $\begin{array}{l}0.013 * * \\
(2.33)\end{array}$ & \\
\hline \multicolumn{3}{|l|}{ Village characteristics } \\
\hline Log of distance to district town $(\mathrm{Km})$ & $\begin{array}{l}0.037 \\
(1.52)\end{array}$ & $\begin{array}{l}-0.050 \\
(-0.72) \\
\end{array}$ \\
\hline \multicolumn{3}{|l|}{ Province dummies } \\
\hline \multirow[t]{2}{*}{ Buri Ram } & $-0.085 *$ & $0.245 * *$ \\
\hline & $(-1.88)$ & $(2.01)$ \\
\hline \multirow[t]{2}{*}{ Nakhon Phanom } & -0.054 & $-0.643 * * *$ \\
\hline & $(-0.54)$ & $(-5.51)$ \\
\hline Intercept & 0.149 & $1.057 * *$ \\
\hline
\end{tabular}


Table 5b (continued)

\begin{tabular}{l|l|l}
\hline \multirow{2}{*}{ Explanatory variables } & $\begin{array}{l}\text { Adaptation } \\
\text { equation }\end{array}$ & Selection equation \\
\cline { 2 - 3 } & Coefficients & Coefficients \\
\hline Mills & $(0.72)$ & $\mathbf{( 2 . 1 0 )}$ \\
\hline Lambda & & \\
\hline rho & $\mathbf{- 0 . 6 0 1 *}$ & \\
\hline Total observations & $\mathbf{( - 1 . 6 5 )}$ & \\
\hline Wald chi2 & -1.00 & \\
\hline Prob > chi2 & 1361 & \\
\hline SOuce: Auth & 17.21 & \\
\hline & 0.102 & \\
\hline
\end{tabular}

Source: Authors' own calculation

Note: $* p<0.10, * * p<0.05, * * * p<0.01, \mathrm{z}$ statistics in parentheses

committee. Among household characteristics it is shown in Table 6a that the higher the share of household members engaged in agriculture, the more likely the households undertake adaptation measures. The respective coefficient is positive and significant for all adaptation measures except for planting trees although the direction of influence is positive. This result is plausible as households whose major livelihood is in agriculture are more likely to actively meet the challenges of climate change. Indeed, the coefficients for all categories (i.e. changing crop diversity, chemical input management, and water management) are positive and highly significant for four categories. Income of households shows a significant and positive influence on adaptation measures "water management" and "planting more trees" which seems plausible as these measures are related to investments. The coefficients for the variables reflecting the perception of the respondent in the three indicators of climate change, i.e. rainfall, temperature and wind all show a positive sign although not all are significant. Consistent results are found for rainfall which is plausible as indeed rainfall is the major driving factor for productivity of agriculture and changing rainfall patterns may warrant adjustments in many agricultural practices. Temperature is significant for planting more trees and changes in crop diversification such as changing crops or crop varieties. The variable for farmer's perception in the change of wind conditions is significant for "crop diversification" and "planting trees" which seems plausible again. Overall, however, it can be argued that farmer's climate change perceptions prompt them to change their farming system. The significance of all climate related coefficients for planting more trees is a strong indicator that farmers recognize the need for climate change adaptation for a variety of reasons.

The ethnicity variable is only significant for water management which underlines again the importance of collective action which often relies on public support. This indicates that households belonging to the Kinh ethnic majority group may be more likely to undertake adaptation measures. Finally, the significant coefficient for the 
Table 6a Results of multinomial logit model for the choice of adaptation measures, Vietnam

\begin{tabular}{|c|c|c|c|c|}
\hline Explanatory variables & $\begin{array}{l}\text { Crop } \\
\text { diversification }\end{array}$ & $\begin{array}{l}\text { Chemical input } \\
\text { management }\end{array}$ & \begin{tabular}{|l} 
Water \\
management
\end{tabular} & Planting trees \\
\hline & coef/se & coef/se & coef/se & coef/se \\
\hline \multicolumn{5}{|l|}{$\begin{array}{l}\text { Household head } \\
\text { characteristics }\end{array}$} \\
\hline \multirow[t]{2}{*}{ Age (Years) } & $-0.015^{*}$ & $-0.017 * *$ & $-0.016^{*}$ & -0.045 \\
\hline & $(0.009)$ & $(0.008)$ & $(0.009)$ & $(0.031)$ \\
\hline \multirow{2}{*}{$\begin{array}{l}\text { Education (Years of } \\
\text { schooling) }\end{array}$} & 0.014 & 0.010 & -0.010 & 0.070 \\
\hline & $(0.027)$ & $(0.021)$ & $(0.024)$ & $(0.111)$ \\
\hline \multirow{2}{*}{$\begin{array}{l}\text { Gender }(1=\text { Male } \\
0=\text { Female })\end{array}$} & 0.471 & 0.378 & 0.332 & -0.384 \\
\hline & $(0.298)$ & $(0.233)$ & $(0.257)$ & $(0.759)$ \\
\hline \multirow{2}{*}{$\begin{array}{l}\text { Member of socio- } \\
\text { political organization } \\
(1=\text { Yes, } 0=\text { No })\end{array}$} & 0.178 & 0.329 & $0.568 * * *$ & 1.627 \\
\hline & $(0.222)$ & $(0.219)$ & $(0.198)$ & $(0.990)$ \\
\hline \multicolumn{5}{|l|}{$\begin{array}{l}\text { Household } \\
\text { characteristics }\end{array}$} \\
\hline \multirow{2}{*}{$\begin{array}{l}\text { Agricultural member } \\
\text { ratio }\end{array}$} & $1.250 * * *$ & $0.986 * * *$ & $0.736 * *$ & 1.928 \\
\hline & $(0.364)$ & $(0.299)$ & $(0.324)$ & $(1.357)$ \\
\hline \multirow[t]{2}{*}{ Log of farm size (ha) } & 0.061 & 0.066 & $0.214 * *$ & 0.362 \\
\hline & $(0.098)$ & $(0.073)$ & $(0.084)$ & $(0.220)$ \\
\hline \multirow[t]{2}{*}{ Log of income (PPP\$) } & $0.219 * *$ & 0.038 & $0.299 * * *$ & $0.678 * * *$ \\
\hline & $(0.105)$ & $(0.087)$ & $(0.094)$ & $(0.262)$ \\
\hline \multirow{2}{*}{$\begin{array}{l}\text { Rainfall perception } \\
(1=\text { Yes, } 0=\text { No })\end{array}$} & $1.607 *$ & $17.775 * * *$ & $1.635 * *$ & $13.515 * * *$ \\
\hline & $(0.977)$ & $(0.326)$ & $(0.798)$ & $(0.803)$ \\
\hline \multirow{2}{*}{$\begin{array}{l}\text { Temperature } \\
\text { perception }(1=\text { Yes, } \\
0=\text { No })\end{array}$} & 0.973 & 0.631 & 0.953 & $15.283 * * *$ \\
\hline & $(0.756)$ & $(0.393)$ & $(0.650)$ & $(0.581)$ \\
\hline \multirow{2}{*}{$\begin{array}{l}\text { Wind perception } \\
(1=\text { Yes, } 0=\text { No })\end{array}$} & $0.736 * * *$ & 0.080 & 0.105 & $1.800 * * *$ \\
\hline & $(0.192)$ & $(0.163)$ & $(0.180)$ & $(0.697)$ \\
\hline \multirow{2}{*}{$\begin{array}{l}\text { Risk attitude (Likert } \\
\text { scale) }\end{array}$} & 0.047 & -0.001 & 0.021 & -0.166 \\
\hline & $(0.043)$ & $(0.029)$ & $(0.035)$ & $(0.105)$ \\
\hline \multirow{2}{*}{$\begin{array}{l}\text { Ethinicity }(1=\text { Kinh, } \\
0=\text { others })\end{array}$} & 0.102 & 0.291 & $0.374 *$ & 0.714 \\
\hline & $(0.255)$ & $(0.237)$ & $(0.223)$ & $(0.956)$ \\
\hline \multicolumn{5}{|l|}{ Village characteristics } \\
\hline $\begin{array}{l}\text { Log of distance to } \\
\text { district town }(\mathrm{Km})\end{array}$ & -0.084 & 0.021 & -0.080 & 0.340 \\
\hline
\end{tabular}


Table 6a (continued)

\begin{tabular}{l|l|l|l|l}
\hline Explanatory variables & $\begin{array}{l}\text { Crop } \\
\text { diversification }\end{array}$ & $\begin{array}{l}\text { Chemical input } \\
\text { management }\end{array}$ & $\begin{array}{l}\text { Water } \\
\text { management }\end{array}$ & Planting trees \\
\hline & coef/se & coef/se & coef/se & coef/se \\
\hline Province dummies & $(0.118)$ & $(0.094)$ & $(0.099)$ & $(0.284)$ \\
\hline Thua Thien Hue & -0.220 & -0.137 & -0.083 & 1.687 \\
\hline & $(0.292)$ & $(0.211)$ & $(0.293)$ & $(1.044)$ \\
\hline Dak Lak & $\mathbf{0 . 5 5 6} * *$ & $\mathbf{- 1 . 0 7 0} * * *$ & $\mathbf{1 . 2 0 3} * * *$ & 0.398 \\
\hline Constant & $(\mathbf{0 . 2 6 2})$ & $\mathbf{( 0 . 2 6 0 )}$ & $\mathbf{( 0 . 2 4 0 )}$ & $(1.102)$ \\
\hline & $\mathbf{- 7 . 2 0 0} * * *$ & $\mathbf{- 2 0 . 0 0 9} * * *$ & $\mathbf{- 7 . 3 7 1} * * *$ & $\mathbf{- 4 0 . 9 9 3 * * *}$ \\
\hline Base category & $(\mathbf{1 . 1 7 3})$ & $\mathbf{( 0 . 9 0 1 )}$ & $\mathbf{( 1 . 0 5 7 )}$ & $\mathbf{( 2 . 2 3 3 )}$ \\
\hline $\begin{array}{l}\text { Number of } \\
\text { observations }\end{array}$ & No adaptation & & & \\
\hline Log likelihood & 1529 & & & \\
\hline LR chi2 & -1505.473 & & & \\
\hline Pseudo R2 & $\mathbf{3 5 3 . 0 8 * * *}$ & & & \\
\hline Source: Auth & 0.136 & & & \\
\hline
\end{tabular}

Source: Authors' own calculation

Note: $* * * \mathrm{p}<0.01, * * \mathrm{p}<0.05, * \mathrm{p}<0.1$

province dummy of Dak Lak indicates the importance of irrigation and crop diversification is this land locked region compared to the coastal provinces of Thua Thien Hue and Ha Tinh.

In summary, the model for Vietnam shows satisfactory results. It largely confirms the finding of our first model (binary model 1a) and provides further information on the factors that drive specific adaption measures. The results can provide information for extension services to guide farmers in adopting more climate smart technologies.

The model for Thailand shows less explanatory power than the Vietnam model. Although the coefficients generally have the expected signs, much fewer of them are significant. Interestingly, however, individual attitude towards risk of the respondent pops up in two of the four categories of adaptation measures with a positive and significant coefficient. This is plausible as risk seeking behaviour may make farmers more likely to undertake climate change adaptation measures. This however was not observed in the Vietnam model. On the other hand, the coefficients for the three climate change indicators are quite consistent with the Vietnam model although wind speed seems to be a stronger factor in Thailand in explaining agricultural adjustments to climate change. The negative coefficient for the province dummy variable for Buri Ram is consistent with the binary model but does not match with the climate-related shock experience shown in the descriptive statistics. In summary, while the Thailand model is less satisfactory the main message that climate change perception is a major driver for specific adaption measures in agriculture can be confirmed. 
Table 6b Results of multinomial logit model for the choice of adaptation measures, Thailand

\begin{tabular}{|c|c|c|c|c|}
\hline Explanatory variables & $\begin{array}{l}\text { Crop } \\
\text { diversification }\end{array}$ & $\begin{array}{l}\text { Chemical input } \\
\text { management }\end{array}$ & $\begin{array}{l}\text { Water } \\
\text { management }\end{array}$ & Planting trees \\
\hline & coef/se & coef/se & coef/se & coef/se \\
\hline \multicolumn{5}{|l|}{$\begin{array}{l}\text { Household head } \\
\text { characteristics }\end{array}$} \\
\hline \multirow[t]{2}{*}{ Age (Years) } & 0.002 & 0.002 & $0.022 * *$ & 0.017 \\
\hline & $(0.008)$ & $(0.009)$ & $(0.010)$ & $(0.019)$ \\
\hline \multirow{2}{*}{$\begin{array}{l}\text { Education (Years of } \\
\text { schooling) }\end{array}$} & 0.038 & -0.005 & 0.010 & $0.176 * * *$ \\
\hline & $(0.032)$ & $(0.037)$ & $(0.047)$ & $(0.054)$ \\
\hline \multirow{2}{*}{$\begin{array}{l}\text { Gender }(1=\text { Male, } \\
0=\text { Female })\end{array}$} & -0.075 & 0.273 & $0.670 * *$ & 0.447 \\
\hline & $(0.200)$ & $(0.252)$ & $(\mathbf{0 . 3 3 3})$ & $(0.467)$ \\
\hline \multirow{2}{*}{$\begin{array}{l}\text { Member of socio- } \\
\text { political organization } \\
(1=\text { Yes, } 0=\text { No })\end{array}$} & -0.845 & 0.358 & 0.212 & -0.924 \\
\hline & $(0.552)$ & $(0.403)$ & $(0.465)$ & $(1.003)$ \\
\hline \multicolumn{5}{|l|}{$\begin{array}{l}\text { Household } \\
\text { characteristics }\end{array}$} \\
\hline \multirow{2}{*}{$\begin{array}{l}\text { Agricultural member } \\
\text { ratio }\end{array}$} & 0.182 & -0.185 & 0.451 & 0.348 \\
\hline & $(0.344)$ & $(0.372)$ & $(0.446)$ & $(0.511)$ \\
\hline \multirow[t]{2}{*}{ Log of farm size (ha) } & -0.113 & 0.050 & -0.150 & -0.279 \\
\hline & $(0.099)$ & $(0.129)$ & $(0.152)$ & $(0.281)$ \\
\hline \multirow[t]{2}{*}{ Log of income (PPP\$) } & 0.088 & 0.036 & -0.000 & -0.071 \\
\hline & $(0.088)$ & $(0.102)$ & $(0.133)$ & $(0.198)$ \\
\hline \multirow{2}{*}{$\begin{array}{l}\text { Rainfall perception } \\
(1=\text { Yes, } 0=\text { No })\end{array}$} & 1.286 & $16.749 * * *$ & 0.944 & $14.083 * * *$ \\
\hline & $(1.115)$ & $(0.591)$ & $(1.025)$ & $(0.388)$ \\
\hline \multirow{2}{*}{$\begin{array}{l}\text { Temperature } \\
\text { perception }(1=\text { Yes, } \\
0=\mathrm{No})\end{array}$} & 1.747 & -0.447 & $15.678 * * *$ & $12.952 * * *$ \\
\hline & $(1.558)$ & $(0.719)$ & $(0.709)$ & $(0.588)$ \\
\hline \multirow{2}{*}{$\begin{array}{l}\text { Wind perception } \\
(1=\text { Yes, } 0=\text { No })\end{array}$} & $0.453 * *$ & $0.796 * * *$ & 0.476 & $2.443 * *$ \\
\hline & $(0.229)$ & $(\mathbf{0 . 3 0 4})$ & $(0.328)$ & $(1.042)$ \\
\hline \multirow{2}{*}{$\begin{array}{l}\text { Risk attitude (Likert } \\
\text { scale) }\end{array}$} & $0.085 * * *$ & 0.046 & $0.112 * *$ & $-0.160 *$ \\
\hline & $(\mathbf{0 . 0 3 3 )}$ & $(0.036)$ & $(0.045)$ & $(0.094)$ \\
\hline \multicolumn{5}{|l|}{$\begin{array}{l}\text { Village } \\
\text { characteristics }\end{array}$} \\
\hline \multirow{2}{*}{$\begin{array}{l}\text { Log of distance to } \\
\text { district town }(\mathrm{Km})\end{array}$} & 0.044 & $0.434 * * *$ & 0.044 & 0.034 \\
\hline & $(0.132)$ & $(0.152)$ & $(0.181)$ & $(0.198)$ \\
\hline
\end{tabular}


Table 6b (continued)

\begin{tabular}{|c|c|c|c|c|}
\hline Explanatory variables & \begin{tabular}{|l|} 
Crop \\
diversification
\end{tabular} & $\begin{array}{l}\text { Chemical input } \\
\text { management }\end{array}$ & $\begin{array}{l}\text { Water } \\
\text { management }\end{array}$ & Planting trees \\
\hline & coef/se & coef/se & coef/se & coef/se \\
\hline \multicolumn{5}{|l|}{ Province dummies } \\
\hline \multirow[t]{2}{*}{ Buri Ram } & -0.037 & 0.046 & $-1.259 * * *$ & $-0.801 *$ \\
\hline & $(0.191)$ & $(0.217)$ & $(0.318)$ & $(0.441)$ \\
\hline \multirow[t]{2}{*}{ Nakhon Phanom } & $-0.819 * * *$ & -0.523 & $-2.441 * * *$ & $-2.113 * *$ \\
\hline & $(0.314)$ & $(0.365)$ & $(0.715)$ & (1.043) \\
\hline \multirow[t]{2}{*}{ Constant } & $-6.382 * * *$ & $-20.852 * * *$ & $-21.526 * * *$ & $-33.101 * * *$ \\
\hline & (1.298) & (1.214) & $(1.441)$ & (2.448) \\
\hline Base category & $\begin{array}{l}\text { No } \\
\text { adaptation }\end{array}$ & & & \\
\hline $\begin{array}{l}\text { Number of } \\
\text { observations }\end{array}$ & 1361 & & & \\
\hline Log likelihood & -1174.558 & & & \\
\hline LR chi2 & $176.10 * * *$ & & & \\
\hline Adjusted R2 & 0.089 & & & \\
\hline
\end{tabular}

Source: Authors' own calculation

Note: $* * * \mathrm{p}<0.01, * * \mathrm{p}<0.05, * \mathrm{p}<0.1$

\section{Summary and Conclusions}

Using a comprehensive dataset of farm households in Thailand and Vietnam we have tried to answer three questions. Firstly, we wanted to explore what climate related shocks farm households experience in the more recent past and whether they perceive a change in the longer term climate conditions and what indicators they use to describe climate change. Secondly, what factors influence their climate change perceptions and can their perceptions be linked to their adaptation measures. Thirdly, we wanted to know to what extent the explanatory factors differ for specific climate change adaptation measures.

The answer to the first question is quite clear. The majority of farm households in both countries have experienced recent climate-related shocks and the vast majority does perceive that climate has changed. While the latter fact may not be very surprising our results however point out that farmers have their own way of describing the climate change related phenomenon. We can also see that quite consistent with differences in natural and economic conditions, the geographic location has an influence on how farmers recognize climate change. Furthermore, farmers reported adjustment measures which they are planning to undertake or have already undertaken in response to climate change. We have independently checked this claim by comparing some climate relevant agricultural practices from our 2007 survey with 
the most recent survey in 2013 and we found quite some differences that suggest that farmers are indeed climate-responsive although we cannot judge to what degree these changes fit the metaphor of "climate-smart".

To answer the second question we used a Heckman model that allows joint estimation of a selection and an outcome equation, separately for the two countries. Based on the results we can confirm that perceptions can be reasonably linked to farmers' decision to undertake adaptation measures. In the model for Vietnam we can show that perceptions are shaped by the respondent's characteristics, location variables and recent climate related shocks. Unfortunately, results for the Thailand model are less convincing. However, the climate-related shock variable is significant and consistent with the results in Vietnam. Similar results were found for the outcome equation where again the Vietnam model was more convincing. The difference could be attributed to the lower awareness among the Thai farmers as shown in the lower number of cases in spite of largely equal initial sample size between the two countries. From an objective point of view, Vietnam is indeed more exposed to climate change due to its geographic location along the South China Sea costal line.

Finally, the answer to the third question is that the factors that drive specific climate change related adaption measures differ among practices, provinces and countries. They are to be found in the characteristics of the respondent and the household head whenever there is a difference between the two. Perhaps the most important factor in explaining specific adaptation measures are the three specific climate variables namely rainfall, temperatures and wind, which are all significantly correlated with tree plantation. While for the other adaptation measures such as crop diversification, varietal change, etc. factors other than climate change may be more important, the clearest connection we find is with trees.

We believe our results can provide important information to policy makers and agricultural extension services who should improve their understanding of the farmers' interpretation of climate change and the constraints that have so far prevented them from undertaking more and better adaption measures. Further studies should take a more in-depth look at those constraints and provide a detailed assessment of the costs and benefits of farmer-based adaption measures.

\section{References}

Asfaw A, Admassie A (2004) The role of education on the adoption of chemical fertilizer under different socioeconomic environments in Ethiopia. Agricultural Economics 30:215-228

Asian Development Bank (ADB) (2009) The Economics of Climate change in Southeast Asia: A Regional Review. Asian Development Bank, Manila

Boonpragob K (2005) Crisis or Opportunity: Climate Change Impacts and Thailand. Greenpeace Southeast Asia, Thailand

Boonyawat J, Chiwanno S (2007) Origin and One Decade of Global Change Study in Thailand. In: Boonyawat J (ed) Southeast Asia START Regional Center and a Decade of Global Change in Thailand. Southeast Asia Global Change System for Analysis, Research and Training. 
Croppenstedt A, Demeke M, Meschi MM (2003) Technology adoption in the presence of constraints: The case of fertilizer demand of Ethiopia. Review of Development Economics 7:58-70

Cuong N (2008) Viet Nam Country Report-A Regional Review on the Economics of Climate Change in Southeast Asia. Report submitted for RETA 6427: A Regional Review of the Economics of Climate Change in Southeast Asia. Asian Development Bank, Manila

Dasgupta S, Laplante B, Meisner C et al (2007) The Impact of Sea Level Rise on Developing Countries: A Comparative Analysis. World Bank Policy Research Working Paper 4136,

Deressa T, Hassan RM, Alemu T et al (2008) Analyzing the Determinants of Farmer's Choice of Adaptation Methods and Perceptions of Climate Change in the Nile Basin of Ethiopia. International Food Policy Research Institute Discussion Paper 00798

Dohmen T, Falk A, Huffman D et al (2011) Individual risk attitudes: Measurement, determinants, and behavioral consequences. Journal of the European Economic Associations 9(3):522-550

Feder G, Just RE, Zilberman D (1985) Adoption of Agricultural Innovations in Developing Countries: A Survey. Economic Development and Cultural Change 33(2):255-298

Franzel S (1999) Socioeconomic factors affecting the adoption potential of improved tree fallows in Africa. Agroforestry Systems 47:305-321

Fuster J (2002) Physiology of executive functions: The perception-action cycle. In: Stuss DT, Knight R (eds) Principles of the frontal lobe. Oxford University Press, New York, p 96-108

Gbetibouo GA (2009) Understanding Farmers' Perceptions and Adaptations to Climate Change and Variability: The case of the Limpopo Basin, South Africa. International Food Policy Research Institute Discussion Paper 00849.

Greene, W. H. (2003). Econometric Analysis. New Jersey: Pearson Education.

Hardeweg B, Menkhoff L, Waibel H (2013) Experimentally Validated Survey Evidence on Individual Risk Attitudes in Rural Thailand. Economic Development and Cultural Change 61:859-888

Heckman J J (1979) Sample Selection as a Specification Error. Econometrica 47:153-161

Hung PT, Trung LD, Cuong N (2010) Poverty of the Ethnic Minorities in Vietnam: Situation and Chanlleges from the Poorest Communes. Munich Personal RePEc Archive.

Iglesias A, Quiroga S, Diz A (2011) Looking into the Future of Agriculture in a Changing Climate. European Review of Agricultural Economics 38(3):427-447

IPCC (2014) Climate Change 2014: Impacts, Adaptation and Vulnerability. Part B: Regional Aspects. Working Group II Contribution to the Fifth Assessment Report of the Intergovernmental Panel on Climate Change. Cambridge University Press, New York

Jesdapipat S (2008) Thailand Country Report-A Regional Review on the Economics of Climate Change in Southeast Asia. Report submitted for RETA 6427: A Regional Review of the Economics of Climate Change in Southeast Asia. Asian Development Bank, Manila

Kahneman D, Knetsch JL, Thaler RH (1990) Experimental Tests of the Endowment Effect and the Coase Theorem. The Journal of Political Economy 98(6): 1325-1348

Long JS, Freese J (2006) Regression Models for Categorical Dependent Variables Using Stata (2nd ed). Stata Press, Texas

Maddison D (2007) The Perception of and Adaptation to Climate Change in Africa. Policy Reseach Working Paper WPS4308, The World Bank

Norris E, Batie S (1987) Virginia farmers' solid conservation decisions: An application of Tobit analysis. Southern Journal of Agricultural Economics 19:89-97

Puhani, PA (2000) The Heckman Correction for sample selection and its critique. Journal of Economic Surveys 14(1):53-68

Reilly JM, Schimmelpfennig D (1999) Agricultural impact assessment, vulnerability and the scope for adaptation. Climate Change 43:745-788

Tversky A, Kahneman D (1992) Advances in Prospect Theory: Cumulative Representation of Uncertainty. Journal of Risk and Uncertainty 5(4):297-323 
Waibel H, Tongruksawattana S, Voelker M (2013) Voices of the poor in climate change in Thailand and Vietnam. In: Ananta A, Bauer A, Thant M (eds) The Environments of the Poor in Southeast Asia, East Asia and the Pacific. Asian Development Bank, Singapore, p 170-186

Weber EU (2010) What shapes perceptions of climate change? Wires Climate Change 332-342 Wooldridge, JM (2009) Introductory Econometrics: A modern approach. South-Western Cengage Learning, p 562

Open Access This chapter is distributed under the terms of the Creative Commons AttributionNonCommercial-ShareAlike 3.0 IGO license (https://creativecommons.org/licenses/by-nc-sa/3.0/ igo/), which permits any noncommercial use, duplication, adaptation, distribution, and reproduction in any medium or format, as long as you give appropriate credit to the Food and Agriculture Organization of the United Nations (FAO), provide a link to the Creative Commons license and indicate if changes were made. If you remix, transform, or build upon this book or a part thereof, you must distribute your contributions under the same license as the original. Any dispute related to the use of the works of the FAO that cannot be settled amicably shall be submitted to arbitration pursuant to the UNCITRAL rules. The use of the FAO's name for any purpose other than for attribution, and the use of the FAO's logo, shall be subject to a separate written license agreement between the FAO and the user and is not authorized as part of this CC-IGO license. Note that the link provided above includes additional terms and conditions of the license.

The images or other third party material in this chapter are included in the chapter's Creative Commons license, unless indicated otherwise in a credit line to the material. If material is not included in the chapter's Creative Commons license and your intended use is not permitted by statutory regulation or exceeds the permitted use, you will need to obtain permission directly from the copyright holder.

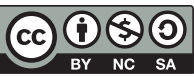

